\title{
Turning Digitisation into Disruption
}

\section{Stephan BAURIEDEL}

Ekonomická univerzita v Bratislave; Bratislava; Slovenská republika; bauriedel@digital-action.de

\begin{abstract}
Digitisation can lead to disruption. This theory describes four steps that allow an entrepreneur to actively shape disruption. The goal is to show the entrepreneur a pragmatic way to take advantage of the business benefits of digitisation. If disruption of markets is possible, the entrepreneur should go for it. This concept comprises points which need to be connected. The starting point is digitisation and the goal is disruption. It is known that platforms reduce transaction costs and that the reduction can lead to a possible monopoly. All four points were first examined, then the connecting steps were added, arranged in a chain of effects and supported by arguments. The chain of effects describes the process that transforms digitisation into disruption. The result shows four steps that an entrepreneur must address after going-live in order to reap the benefits of digitisation. It also illustrates that cost reduction determines the leverage for disruption. Thus, cost reduction becomes the primary goal of any digital strategy. Knowing the chain of effects demystifies disruption for the entrepreneur.
\end{abstract}

Keywords: digitisation; disruption; entrepreneurship

JEL Classification: O33; O44; M21

\section{Introduction}

Digitisation can lead to disruption. Disruption is a threat for every company. But if disruption is possible, the company must go for it. Otherwise, a competitor or a new entrant will do it and overtake. A disruption comes quickly and violently. Well-known examples of this are Nokia and Kodak.

To foresee the impact of digitisation is difficult for the entrepreneur, because the digital world is subject to different laws. It is necessary to decipher the new success factors and use them for oneself. The theory presented here states that digitization is a business objective. After the successful transformation, however, another goal emerges: disruption. It takes both goals to be successful. This article examines argumentatively which steps are necessary that digitisation leads to disruption.

Digitisation is closely linked to disruption. For anyone to observe, Uber has completely transformed the cab business and iTunes has completely changed music distribution in a short period of time. Salim Ismail states in the context of his theory of exponential organisations, "An information-based environment creates fundamentally disruptive opportunities." (Ismail et al., 2017)

There are many descriptions of digitisation in the literature. Klaus Macharzina calls it a technology that connects people and therefore companies (Macharzina \& Wolf, 2018). Klaus Schwab describes it as the "fourth industrial revolution" (Schwab, 2016) and Peter Glaser 
marks it as an inevitable event: "Everything that can be digitised will be digitised. Everything." (Glaser) It quickly becomes apparent that digitisation is a nebulous homonym. The author has begun to elaborate the characteristics of digitisation by comparing the way internet startups like Uber, Airbnb, and Booking.com work with the way analog organisations work. The result is the following definition: "Digitisation is an epochal leap in productivity with the character of an industrial revolution." This definition describes why digitisation is both an opportunity and a threat.

Disruption encompasses various theories, which build on each other. Joseph A. Schumpeter (Schumpeter, 1942) advocated the theory of the constant renewal of markets as early as 1942. He assumed that an idea is suitable until a new, better idea replaces the old one. Richard Foster (Foster, 1986) stated in 1986 that there is a dependency between the effort for improvements of a technology and its performance. He developed the first S-curve model. Clayton Christensen (Christensen, 2016) later took Foster's idea and extended the model to a multiple S-curve model. He recognized that disruptive innovations initially perform worse. At a certain point, the new technology overtakes - in rapid steps - the predecessor and becomes the leading technology. Rebecca Henderson (Henderson \& Clark, 1990), a professor at Harvard University, created the term Architectural Innovation. She does not consider a product as a whole, but divides it into different components and thus examined the structure. Architectural Innovation in this context is a great challenge for companies because the structure of the product changes. The basic structure of the product is different and the knowledge about the design of the product is erupted. Finally, Joshua Gans defined the term disruption as follows: "I define disruption as what a firm faces when the choices that once drove a firm's success now become that destroy its future." (Gans, 2017)

In the context of this paper, two other characteristics of digitisation are worth mentioning. First, there is evidence that digitisation lowers marginal costs, and second, there is a phenomenon of monopoly formation. Digitisation significantly changes the cost structures of companies. Fixed costs increase and variable costs decrease. The implementation of a digital strategy requires investments in building the platform, while transaction costs are reduced to a minimum. Hagen Krämer (Krämer, 2019) shows in his working paper how the costs of an industrial product change compared to a digital product. Building the platform results in the first transaction having the highest cost and for each subsequent transaction the marginal cost remains constant at a minimum. This phenomenon is called first copy cost. In contrast to industrial costs, product costs fall steadily with output quantity (unit cost degression (Clement et al., 2019)). Florian Bartholomae (Bartholomae, 2018) studied two different effects, gradual and drastic cost reduction, in his working paper. While gradual cost reduction results in a shift in competition, Bartholomae assumes that drastic cost reduction can lead to a monopoly. This phenomenon is called "the winner takes it all" (Clement et al., 2019) and describes how the digitisation of business models can lead to a single dominant provider. 


\section{Methodology}

Digitisation shows the character of an industrial revolution, as it has technological, managerial and social implications. The state of the problem demonstrates that there are very many isolated theories, which do not mesh well. This paper focuses on pragmatic recommendations for action for an entrepreneur who is already established in the market (B2B) and is planning a digital strategy.

\subsection{The Missing Link}

The methodology to develop the theory listed here is relatively simple. Several times it is stated in literature that disruption can be triggered by digitisation, but there is no guidance or theory on how to actively bring about disruption. The author has developed the Digital Action model (Bauriedel, 2020c), which breaks down the development of a digital strategy into 7 planning steps. The model is used to transform an analogue organisation into a platform-oriented business model. It has been shown that the going-live of the platform is not the end. The technical goal of digitisation is achieved, but there is no connection to disruption. The first insight is that after the completion of the digital transformation, the process should go further. There is a gap between digitisation and really disruptive change that no one had described before.

\subsection{Connecting the Dots}

The second step was to identify all the known fixed points. The idea is that digitisation is the starting point and disruption is the result. The connection between the two points would be a process (Hammer \& Champy, 1994) with several sequential steps necessary to achieve this outcome. The goal of digitisation is to systematically replace manual and intellectual work in operational processes ("algorithms replace employees" (Bauriedel, $2020 \mathrm{~b})$ ). Therefore, digitisation leads to a reduction in costs. The entrepreneur now has two options: increase profits or reduce prices. Higher returns are lucrative, but they do not lead to disruption. And it does not solve the problem of third-party disruption. Therefore, the next logical step is to lower prices. The measure that the company must take after digitisation is price reduction. Interestingly, it is not mentioned in connection with digitisation. And it will be necessary to launch marketing activities to publicise the price advantage and to draw attention to the platform.

\subsection{Creating a Theory}

The methodology for the theory was to observe, question and conclude. The chain of effects established shows analogy to other epochal developments, such as the steam engine. But in a digital world time for action is much shorter. Therefore, the entrepreneur needs from the beginning a strategy for digitisation and a second strategy for disruption. The task was to provide an argumentative support to this theory. An upcoming multi-case study will test the theory on companies who have already gone through the digital transformation. 


\subsection{Work experience}

The author also has 30 years of experience in strategy, business, technology and change. As a management consultant, he has gained deep knowledge of the organisational structure of companies and their IT infrastructure in numerous projects. He has been researching and publishing on digital strategies and their implementation for five years (Bauriedel, 2017).

\section{Results}

The operation of the platform is not the end of the digital strategy, but the beginning of disruption. The company has realised a leap in productivity with digitisation, which must now be exploited consistently. The micro-economists have recognised that digitisation reduces transaction costs and they have observed that this can lead to monopoly formation. From the entrepreneur's point of view, the connecting steps to actively shape the results are missing. Considering the laws of business management, the following intermediate goals (Figure 1) are required to make digitisation a success: Drastically reduce costs, significantly reduce prices, explosively increase volume and successively take over market share. The emphasis is on drastic and explosive, because we are not talking about incremental improvement, but about a leap in productivity of ten percent and more.

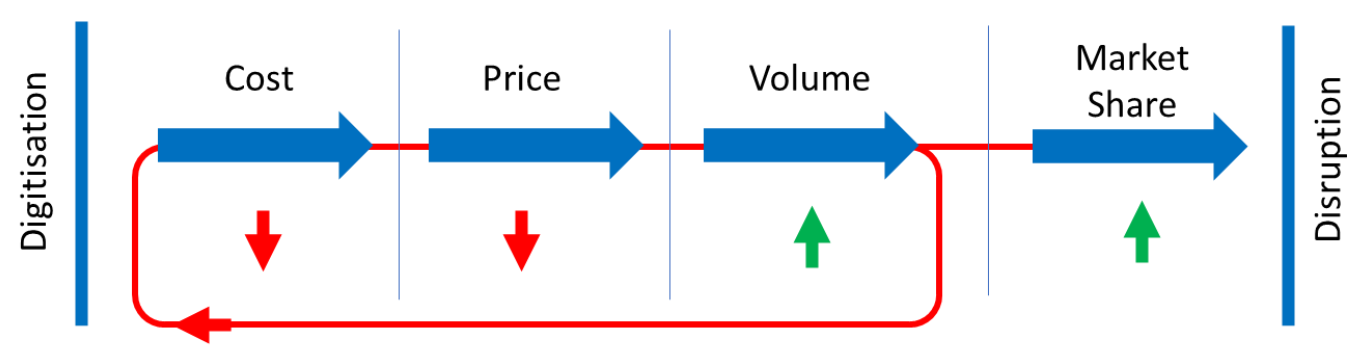

Figure 1. Chain of effects for digital success.

Costs - Digitisation is a cost killer. It minimises transaction costs and has an impact on all subsequent costs. The first goal of any digital strategy should therefore be to reduce costs. An industrial company, for example, typically has a strong sales force that accounts for 20 percent of costs and downstream marketing that comprises five percent of costs. That means 25 percent of the price achieved is spent on initiating business. With a digital strategy based on online marketing, a sales platform and personal support for all key accounts, the costs for marketing and sales would only be an estimated ten percent. All A customers, which account for 80 percent of the business, would continue to receive individual support via key account management and all B and C customers would be redirected to the platform. An estimate by the author states that digitisation enables a cost reduction of ten to 99 percent. The minimum goal here is achieved simply by eliminating work in operational processes, and the maximum goal when converting to a digital asset.

Prices - In tight markets, there is constant price competition. Firms are subject to the Bertrand principle (Clement et al., 2019, p. 71), where price is oriented just above marginal cost. If a market player exploits the cost advantages of digitisation, it can offer its products 
far below the marginal costs of the competition. Therefore, the first step - reducing costs determines the leverage effect of the following steps. After all the higher the cost reduction the more aggressive the price reduction.

The second step in the chain of effects has as its goal to lower prices and to do so as much as possible. Jeremy Rifkin states in his book "The Zero Marginal Cost Society" that a productivity gain through innovation always leads to lower costs and lower prices. He writes, "Attempts to inhibit economic progress are inevitably doomed to failure because new entrepreneurs are constantly lurking at the margins of the system, their eyes open for innovations that increase productivity and reduce costs, which allows them to go after consumers with lower prices than their competitors." (Rifkin, 2014)

Chris Anderson argues this move by citing one of Bertrand's conclusions, "that firms are more likely to cut prices to increase market share than to cut production in order to impose higher prices in the marketplace" (Anderson et al., 2009). He has also described in detail in his book "Free" how companies attract customers by offering a free service. If marginal costs are close to zero, parts of the offering can be made available for free in order to promote the paid offerings.

Volume - An aggressive price cut changes customer behavior and markets. Customers react quickly to price cuts and start to switch providers. In addition, German industrial companies have a low return on sales of only two to four percent (Statista $\mathrm{GmbH}, 2020$ ). Due to the low return and high marginal costs, competitors cannot counter a drastic price reduction of ten to 20 percent. The digital provider gradually takes over the business volume of the analog competitors. In this third step of the chain of effects, the aim is to bring about an explosion in business volume. All measures that lead to exponential growth must be applied.

According to the Jevons paradox (Jevons, 1866), a lower price also leads to an increase in consumption. That is, by having a high availability and a low price, the market grows. Peter Diamandis (Diamandis \& Kotler, 2012) in his book "Abundance" even speaks of waste. He argues that a scarce good can become a product in abundance due to the continuous innovations. Salim Ismail (Ismail et al., 2017) takes up this idea and describes how digital goods in particular (photos, music and movies) grow from scarce goods to exponentially consumed products.

Market share - The increasing volume of business shifts market shares. It can be assumed that market shares by revenue will initially fall as a result of the drastic price reduction and then quickly grow again. Market shares by products sold will increase immediately after the price reduction. As is well known, the unit cost regression already mentioned leads to further cost savings, which should be used for an additional price reduction and then leads to even more volume. Dominance is only properly applied when the competitor gives up. This phenomenon is called "the winner takes it all" and illustrates that the digitisation of business models can lead to a single dominant supplier.

\section{Discussion}

Digitisation is difficult to describe. Politicians, associations and entrepreneurs refer to digitisation as the topic of the future and yet cannot explain it. Digitisation eliminates all 
employees in operational processes and replaces them with a platform. Platforms reduce transaction costs to zero and increase output to infinity. Amazon.com can serve a billion customers simultaneously while offering 200 million products (Brandt, 2017) around the clock. The three levers of productivity, capital, labor and resources, are erupted. It takes less capital, no labor, and digital goods require no resources (Bauriedel, 2020a). The conventional thinking no longer works.

It is hard for the entrepreneur to accept the new success factors, having been very successful in his former business for decades. Micro-economists have recognised that digitisation reduces transaction costs and they have observed that this can lead to monopoly formation. From the entrepreneur's point of view, the connecting steps to actively shape the results are missing. The question I followed was: "How did Uber became an internet giant." If you ask the entrepreneur, he thinks they are smart. If you ask the technology providers, they talk about web, app and cloud. If you ask the digital consultants, they explain the business model to you. So how does it come that Uber became a giant and all the others failed? I believe the chain of effects for digital success shows the invisible master plan behind a disruptive strategy. The visible part of Uber is the app, but the invisible part consists of a destructive price war for dominance in the passenger transportation segment. Uber cut the price for the ride and delivers high volumes at the same time. If it appears to be so obvious, why do all the others fail?

In summer 2021, the theory will be further investigated in an upcoming multi-case study. Several entrepreneurs who claim that they have already digitized their company will be surveyed. For this purpose, dedicated system queries will be initiated in the companies' business applications to build up an objective database. The aim is to record the impact of the digital transformation on the company's results. A partial result is the verification or rejection of the theory stated here.

\section{References}

Anderson, C., Schöbitz, B., \& Vode, D. (2009). Free - Kostenlos: Geschäftsmodelle für die Herausforderungen des Internets. Campus-Verl.

Bartholomae, F. W. (2018). Ökonomische Auswirkungen der Digitalisierung auf den internationalen Wettbewerb und die internationale Arbeitsteilung. SSRN Electronic Journal. Advance online publication. https://doi.org/10.2139/ssrn.3218164

Bauriedel, S. (2017). Die Digitalisierung der Geschäftsmodelle: Die 18 wichtigsten Business Cases für digitale Geschäftsmodelle in der Industrie. Unternehmensberatung.

Bauriedel, S. (2020a). Die drei Killerargumente für die Digitalisierung. www.digital-action.de

Bauriedel, S. (2020b). Die fünf Gesetze der Digitalisierung. www.digital-action.de

Bauriedel, S. (2020c). Procedure model for the developement of digital strategies. In P. Ondra (Ed.), DOKBAT 2020 - 16th International Bata Conference for Ph.D. Students and Young Researchers (pp. 49-56). Tomas Bata University in Zlín. https://doi.org/10.7441/dokbat.2020.04

Brandt, M. (2017). 229 Millionen Produkte auf Amazon.de. https://de.statista.com/infografik/7849/bei-amazon-deutschland-gelistete-produkte/

Christensen, C. M. (2016). The Innovator's Dilemma: When new technologies cause great firms to fail. The management of innovation and change series. Harvard Business Review Press.

Clement, R., Schreiber, D., \& Bossauer, P. (2019). Internet-Ökonomie: Grundlagen und Fallbeispiele der digitalen und vernetzten Wirtschaft. Lehrbuch. 
Diamandis, P. H., \& Kotler, S. (2012). Abundance: The future is better than you think. Free Press. http://www.loc.gov/catdir/enhancements/fy1205/2011039926-s.html

Foster, R. N. (1986). Innovation: The attacker's advantage. Summit Books.

Gans, J. (2017). The Disruption Dilemma (MIT Press new paperback edition). The MIT Press.

Glaser, P. Aussage Digitalisierung.

Hammer, M., \& Champy, J. (1994). Reengineering the Corporation: A manifesto for business revolution. Harper Business.

Henderson, R. M., \& Clark, K. B. (1990). Architectural Innovation: The Reconfiguration of Existing Product Technologies and the Failure of Established Firms. Administrative Science Quarterly, 35(1), 9. https://doi.org/10.2307/2393549

Ismail, S., Malone, M. S., \& van Geest, Y. (2017). Exponentielle Organisationen: Das Konstruktionsprinzip für die Transformation von Unternehmen im Informationszeitalter. Verlag Franz Vahlen.

Jevons, W. S. (1866). The Coal Question: An Inquiry concerning the Progress of the Nation, and the Probable Exhaustion of our Coal-mines. https://oll.libertyfund.org/title/jevons-the-coal-question

Krämer, H. (2019). Digitalisierung, Monopolbildung und wirtschaftliche Ungleichheit. Wirtschaftsdienst, 99(1), 47-52. https://doi.org/10.1007/s10273-019-2394-z

Macharzina, K., \& Wolf, J. (2018). Unternehmensführung: Das internationale Managementwissen: Konzepte - Methoden - Praxis (10. vollständig überarbeitete und erweiterte Auflage). Lehrbuch. Springer Gabler. http://www.springer.com/

Rifkin, J. (2014). Die Null-Grenzkosten-Gesellschaft: Das Internet der Dinge, kollaboratives Gemeingut und der Rückzug des Kapitalismus. Campus Verlag GmbH.

http://search.ebscohost.com/login.aspx?direct=true\&scope=site\&db=nlebk\&AN=1052156

Schumpeter, J. A. (1942). Capitalism, Socialism and Democracy (First edition). Harper.

Schwab, K. (2016). Die vierte industrielle Revolution. Pantheon.

Statista GmbH (Ed.). (2020). Deutsche Metall- und Elektroindustrie - Umsatzrendite bis 2019.

https://de.statista.com/statistik/daten/studie/153677/umfrage/ertragslage-der-metall--und-elektroindustriein-deutschland-seit-1997/ 